\title{
Nurses' Performance in Preventing Healthcare Associated Infections at Murni Teguh Memorial Hospital in 2017
}

\author{
Hadi Marzuki ${ }^{1}$ \\ Student of Magister Public Health \\ University of North Sumatera \\ Medan, Indonesia \\ E-mail : hadi88_mz@yahoo.com
}

\author{
Ida Yustina $^{2}$, Destanul Aulia ${ }^{3}$ \\ Lecturer of Magister Public Health \\ University of North Sumatera \\ Medan, Indonesia
}

\begin{abstract}
High mortality and morbidity due to Healthcare Associated Infections (HAI's) is one of the public health problem. Healthcare associated infections incidence at Murni Teguh Memorial Hospital is still high, such as the incidence of urinary tract infection that reach 14.7 percentile and the incidence of phlebitis reaches 6.8 percentile in certain month. The nurses' performance in preventing healthcare associated infections was not optimized. According to the audit result on December, the nurses' performance in hand hygiene is only $\mathbf{7 4 , 4}$ percent. The study aimed to analyze the individual factors (ability, working experience and demography), organizational factors (facilities and infrastructures and supervision) and psychological factors (attitude, motivation and willingness to learn) which influenced the nurses' performance in preventing healthcare associated infections.This study was a survey. The population were 215 nurses and the sample was 56 nurses in inpatient wards at Murni Teguh Memorial Hospital. The data were collected by using questionnaires and observation. The univariate and bivariate data were analyzed using Chi-Square test, while the multivariate data were analyzed using multiple linear regression test.The results showed that the education level, the facilities and infrastructures and the supervision were the determinant factors that influenced the nurses' performance in preventing healthcare associated infections. The supervision factor was the most dominant factor with a coefficient of 0.419. The nurses' performance in preventing healthcare associated infections can be optimized by the efforts of management commitment to conduct the internal and external training, ongoing monitoring and supervision and support the facilities and infrastructures as well as human resource as needed.
\end{abstract}

Keywords - performance; nurse; preventing; healthcare associated infection

\section{INTRODUCTION}

Hospital is a health facility where healthcare is provided. A good hospital service if there is a good quality service. The quality of health services, especially in hospital can be assessed through various indicators. One of them is the assessment of controlling nosocomial infection which become the standard of accreditation [1].

Nosocomial infection or nowadays known as healthcare associated infections can increase morbidity and mortality.
Nosocomial infections or healthcare associated infections occur in patients under medical care after 48 hours, 3 days after discharge and 30 days after operation. These infections occur worldwide both in developed and developing countries. Various studies showed that nosocomial infection has any potential to increase the severity of illness and emotional stress which is reduce patient quality of life [2]. Based on the literature review conducted by World Health Organization (WHO) from several published research since 1995-2008, it was found that the prevalence of nosocomial infection in developed countries ranged between $5.1-11.6 \%$, while in developing countries ranged between 5-19\% [3]. Nosocomial infection in Indonesia is still one of the causes of mortality and morbidity in hospital or other healthcare facility. Nosocomial infection in 10 academic medical center hospitals in Indonesia is quite high, ranged between $6-16 \%$ in 2010 .

In Medan, surgical site infection is happened at Haji Adam Malik Hospital in 2010 with prevalance rate 5.6\% [4]. Based on healthcare associated infections surveilance at Murni Teguh Memorial Hospital, the incidence of infection is still high, as the incidence of phlebitis reaches $1.7 \%$ in January and $6.8 \%$ in December 2016, mean while recommendation from the ministry of health is below $1.5 \%$. The incidence of urinary tract infection is quite high enough, in January and March 2016 reaches $14.7 \%$, mean while recommendation from the ministry of health is below $4.7 \%$.

The professional nurses working in hospital are recognized for existence in healthcare services. The nurses as person who contacted with patient (for 24 hours) are the front personnel in preventing and controlling healthcare associated infections [1]. Nurses who lack of attention in sterile technique during procedure, longer admission, lower standard treatment and many patient in the room will increase the nosocomial infection [2].

Nurses' performance in preventing healthcare associated infections at Murni Teguh Memorial Hospital has not achieved the expexted result. The audit result that conducted by Infection Control Committee in September 2016 showed that nurses' performance in preventing healthcare associated infections like hand hygiene reached $76.3 \%$. Hand hygiene campaigns within three months from October to December are 
still far behind in giving performance improvement results. The audit result of hand hygiene in December reduced to $74.4 \%$

Performance individual is affected by three factors. First, individual competency consist of training, motivation dan attitude. The second is organization support which is facilities and infrastructure, working environment, health and safety guarantee. The last is management support which is how management to retain the individual performace by supervision directly.

The problem in this study is lack of nurses' performance related to prevention and control healthcare associated infections at Murni Teguh Memorial Hospital. The aim of this study is to analyze nurses' performance in preventing healthcare associated infections at Murni Teguh Memorial Hospital.

\section{METHODOLOGY}

This study was a survey. The study was conducted at Murni Teguh Memorial Hospital from February to September 2017. The population of this study was all nurses in inpatient wards at Murni Teguh Memorial Hospital which amounted to 215 nurses and the sample obtained by the formula of proportion is 56 nurses with simple random sampling using the lottery method.

Tools for data collection used questionnaire and observation method. The questionnaire was made by researcher based on variables of factors that affect performance from Gibson's Theory (2012) and performance of healthcare associated infections prevention according to recommendation of the ministry of health (2008). Data were collected, coded, tabulated and then analyzed. Data analysis was performed using the Statistical Package for Social Sciences (SPSS v.17) for univariate and bivariate analysis using Chi-Square test, while multivariate analysis using multiple linear regression test

\section{RESULTS}

Table 1 presents individual characteristics of the studied samples.

TABLE 1

INDIVIDUAL CHARACTERISTICS OF THE SAMPLE

\begin{tabular}{|l|l|l|l|}
\hline Variables & Category & n & \% \\
\hline \multirow{2}{*}{ Age } & 1. $<25$ years & 26 & 46,4 \\
& 2. $\geq 25$ years & 30 & 53,6 \\
\hline \multirow{2}{*}{ Gender } & 1. Male & 2 & 3,6 \\
& 2. Female & 54 & 96,4 \\
\hline \multirow{2}{*}{ Education Level } & 1. Nursing Diploma & 31 & 55,4 \\
& 2. Bachelor & 25 & 44,6 \\
\hline \multirow{2}{*}{ Working } & 1. <2 years & 23 & 41,1 \\
experience & 2. 22 years & 33 & 58,9 \\
\hline \multirow{2}{*}{ Training course } & 1. Never & 5 & 8,9 \\
& 2. Basic & 46 & 82,1 \\
& 3. Advanced & 5 & 8,9 \\
\hline \multirow{2}{*}{ Ability } & 1. Good & 13 & 23,2 \\
& 2. Poor & 43 & 76,8 \\
\hline
\end{tabular}

It clarifies that most of the studied nurses were female (96.4\%), in the age group $\geq 25$ years $(53.6 \%)$, had diploma degree $(55.4 \%)$, more than two years of working experience $(58.9 \%)$, had followed basic training course $(82.1 \%)$ and poor ability $(76.8 \%)$.

Table 2 presents the organizational factors that influence the nurses performance in preventing healthcare associated infenctions.

TABLE 2

ORGANIZATIONAL FACTORS

\begin{tabular}{|l|l|l|l|}
\hline Variable & Category & n & \% \\
\hline \multirow{2}{*}{ Facility and infrastructure } & 1. Good & 31 & 55,4 \\
& 2. Poor & 25 & 44,6 \\
\hline \multirow{2}{*}{ Supervision } & 1. Good & 51 & 91,1 \\
& 2. Poor & 5 & 8,9 \\
\hline
\end{tabular}

. It clarifies that most of the studied nurses were stated good facilities and infrastructures (55.4\%) and good supervision $(91.1 \%)$.

Table 3 presents the psychological factors. that influence the nurses performance in preventing healthcare associated infenctions.

TABLE 3

PSYCHOLOGICAL FACTORS

\begin{tabular}{|l|l|l|l|}
\hline Variable & Category & $\mathbf{N}$ & $\%$ \\
\hline \multirow{2}{*}{ Motivation } & 1. Good & 54 & 96,4 \\
& 2. Poor & 2 & 3,6 \\
\hline \multirow{2}{*}{ Attitude } & 1. Good & 54 & 96,4 \\
& 2. Poor & 2 & 3,6 \\
\hline Willingness to & 1. Good & 45 & 80,4 \\
learn & 2. Poor & 11 & 19,6 \\
\hline
\end{tabular}

It clarifies that most of the studied nurses had good motivation $(96.4 \%)$, attitude $(96.4 \%)$ and willingness to learn $(80.4 \%)$.

It was found that nurses' performance in preventing healthcare associated infections was good (17.9\%), fair $(64.3 \%)$ and poor $(17.9 \%)$. The majority of them had fair performance level $(64.3 \%)$ in preventing healthcare associated infections. Tabel 4 shows the nurses performance in preventing healthcare associated infections.

TABLE 4

NURSES PERFORMANCE OF THE SAMPLES

\begin{tabular}{|l|l|l|l|}
\hline Variables & Category & n & \% \\
\hline \multirow{3}{*}{ Performance } & 1. Good & 10 & 17,9 \\
& 2. Fair & 36 & 64,3 \\
& 3. Poor & 10 & 17,9 \\
\hline
\end{tabular}

Table 5 present crosstab between the individual characteristic, organization factor, physicology factor and nurses performance in preventing healthcare associated infections. The table 5 also shows that education level factor, facilities and infrastructures factor and supervision factor in relation to nurses' performance have statistically significant difference $\mathrm{P}<0.05$. 
TABLE 5

CHI-SQUARE TEST

\begin{tabular}{|c|c|c|c|c|c|c|c|c|}
\hline \multirow{3}{*}{ Variable } & \multirow{3}{*}{ Category } & \multicolumn{6}{|c|}{ Performance } & \multirow{3}{*}{ P value } \\
\hline & & \multicolumn{2}{|c|}{ Good } & \multicolumn{2}{|c|}{ Fair } & \multicolumn{2}{|c|}{ Poor } & \\
\hline & & $\mathbf{n}$ & $\%$ & $\mathbf{n}$ & $\%$ & $\mathbf{n}$ & $\%$ & \\
\hline \multirow{2}{*}{ Age } & 1. $<25$ years & 4 & 15,4 & 16 & 61,5 & 6 & 23,1 & \multirow{2}{*}{0,618} \\
\hline & 2. $\geq 25$ years & 6 & 20 & 20 & 66,7 & 4 & 13,3 & \\
\hline \multirow{2}{*}{ Gender } & 1. Male & 0 & 0 & 2 & 100 & 0 & 0 & \multirow[t]{2}{*}{0,562} \\
\hline & 2. Female & 10 & 18,5 & 34 & 63 & 10 & 18,5 & \\
\hline \multirow{2}{*}{$\begin{array}{l}\text { Education } \\
\text { level }\end{array}$} & 1. Diploma & 4 & 12,9 & 18 & 58,1 & 9 & 9 & \multirow{2}{*}{0,044} \\
\hline & 2. Bachelor & 6 & 24 & 18 & 72 & 1 & 4 & \\
\hline \multirow{2}{*}{$\begin{array}{l}\text { Working } \\
\text { experience }\end{array}$} & 1. $<2$ years & 4 & 17,4 & 13 & 56,5 & 6 & 6,1 & \multirow{2}{*}{0,396} \\
\hline & 2. $\geq 2$ years & 6 & 18,2 & 23 & 69,7 & 4 & 12,1 & \\
\hline \multirow{3}{*}{$\begin{array}{l}\text { Training } \\
\text { course }\end{array}$} & 1. Never & 1 & 20 & 4 & 80 & 0 & 0 & \multirow{3}{*}{0,873} \\
\hline & 2. Basic & 8 & 17,4 & 29 & 63 & 9 & 19,6 & \\
\hline & 3. Advanced & 1 & 20 & 3 & 60 & 1 & 20 & \\
\hline \multirow{2}{*}{ Ability } & 1. Good & 2 & 15,4 & 7 & 53,8 & 4 & 30,8 & \multirow{2}{*}{0,382} \\
\hline & 2. Poor & 8 & 18,6 & 29 & 67,4 & 6 & 14 & \\
\hline \multirow{2}{*}{$\begin{array}{l}\text { Facilities and } \\
\text { infrastructures }\end{array}$} & 1. Good & 8 & 25,8 & 21 & 67,7 & 2 & 6,5 & \multirow{2}{*}{0,022} \\
\hline & 2. Poor & 2 & 8 & 15 & 60 & 8 & 32 & \\
\hline \multirow{2}{*}{ Supervision } & 1. Good & 10 & 19,6 & 34 & 66,7 & 7 & 13,7 & \multirow[t]{2}{*}{0,031} \\
\hline & 2. Poor & 0 & 0 & 2 & 40 & 3 & 60 & \\
\hline \multirow{2}{*}{ Motivation } & 1. Good & 10 & 18,5 & 34 & 63 & 10 & 18,5 & \multirow{2}{*}{0,562} \\
\hline & 2. Poor & 0 & 0 & 2 & 100 & 0 & 0 & \\
\hline \multirow{2}{*}{ Attitude } & 1. Good & 10 & 18,5 & 34 & 63 & 10 & 18,5 & \multirow[t]{2}{*}{0,562} \\
\hline & 2. Poor & 0 & 0 & 2 & 100 & 0 & 0 & \\
\hline \multirow{2}{*}{$\begin{array}{l}\text { Willingness to } \\
\text { learn }\end{array}$} & 1. Good & 9 & 20 & 29 & 64,4 & 7 & 15,6 & \multirow[t]{2}{*}{0,530} \\
\hline & 2. Poor & 1 & 9,1 & 7 & 63,6 & 3 & 27,3 & \\
\hline
\end{tabular}

The result of the multiple linear regression test showed that the independent variables which have a linear statistical relationship in preventing healthcare associated infections at Murni Teguh Memorial Hospital were education level factor, facility and infrastructure factor and supervision factor, while the others didn't have. As shown in table 6, the supervision factor is the most dominant factor in relation to nurses' performance in preventing healthcare associated infections at Murni Teguh Memorial Hospital.

TABLE 6

THE T TEST

\begin{tabular}{|c|c|c|c|}
\hline \multirow[t]{2}{*}{ Model } & \multicolumn{2}{|c|}{$\begin{array}{l}\text { Unstandardized } \\
\text { Coefficients }\end{array}$} & \multirow{2}{*}{$\begin{array}{c}\begin{array}{c}\text { Standardized } \\
\text { Coefficients }\end{array} \\
\text { Beta } \\
\end{array}$} \\
\hline & B & Std. Error & \\
\hline (Constant) & 1.019 & .698 & \\
\hline Education level & .154 & .178 & .128 \\
\hline Supervision & .419 & .283 & .200 \\
\hline $\begin{array}{l}\text { Facilities and } \\
\text { infrastructures }\end{array}$ & .270 & .182 & .225 \\
\hline
\end{tabular}

\section{DISCUSSION}

The results of the study showed that nurses have fair performance level in preventing healthcare associated infections. Nurses' performance can be improved through passion, motivation, willingness to do their best and responsibility to do practice based on SOP that set by the hospital so can produce the expected performance that leads to the targeted organizational goals [5]. This study showed that good motivation not followed by good performance, this can be caused by several factors such as high workload, lack of responsibility and the absence of reward and punishment system.

Productive age is the range of ages which people achieve a good level of productivity, as well as nurses at Murni teguh are in the productive age range. As in [6], the increased in experience and skills in work as well as the age. Younger age is considered to have little experience and skills so as not to be skilled in preventing healthcare associated infections. This is consistent with present study findings that mostly nurses are in the age group $\geq 25$ years have better performance although there is no relationship between age and nurses' performance in preventing healthcare associated infections.

The results of the study showed that there are no relationship between gender and nurses' performance in preventing healthcare associated infections. There is no difference between consistency in men and women in solving problems, analytical skills, competitive stimulant, motivation, sociability, or learning ability [6].

The results of the study showed that there is a relationship between education level and nurses' performance in preventing healthcare associated infections. Education is the act or process that planned to affect others, either individually, groups, or communities so that they will do as the lecturer expected [7]. As in [8], education will affect a person in making decisions so that the higher the education level, the more understand the person about knowledge and will affect their behaviors, so their compliance behavior also will be higher. Education affects the way of thinking of the individual, in other words the way of thinking of a person with low education will be different from the way of thinking of someone who is highly educated.

The study reported no relationship between working experience and nurses' performance in preventing healthcare associated infections. Unfortunately, someone who has longer working experience is expected to understand more about her work. This is supported by Abdullah, Sidin and Pasinringi (2014) and Setiyawati and Supratman (2008), who said that there is no relationship between working experience and performance [8][9].

An organization needs to involve human resources in training activities [10]. This study revealed that there is no relationship between training course and nurses' performance in preventing healthcare associated infections while this is against to performance theory by Simanjuntak (2005) who said that training is a factor affecting performance [11]. It is an unfortunate fact that infection control training is a hospital investment for nurses to continue improving their ability in preventing nosocomial infections.

The result of the study showed that there is no relationship between ability and nurses' performance in preventing healthcare associated infections. Ability in this study is measured by knowlegde and skill of the nurses. Knowledge is gained through personal experience that occurs repeatedly including the teaching process. If knowledge is good, then performance will be good. Otherwise, if the knowledge is 
poor, then performane become poor. This happens because knowledge is the form of action [12]. Someone who only uses the last knowledge will be left behind its performance than someone who always adds new knowledge.

Facilities and infrastructures is one of the factors that support individuals in work. Employees can not do their best in work without adequate facilities or infarstructures. Present study results revealed that there was a significant relationship between facilities and infrastructures factor and the nurses' performance in the preventing healthcare associated infections. This is supported by Yanti (2014) who said that there was a relationship between the availability of personal protective equipments and nurses' behavior in preventing nosocomial infections. There were three factors which influence a person behavior like predisposing factor, supporting factor and driving factor. Facilities and infrastructures factor as a supporting factor that influence the nurses' performance [12].

This study results showed that there is a relationship between supervision and nurses performance in preventing healthcare associated infections and by statistical test showed that the most dominant factor on nurses' performance in preventing healthcare associated infections was supervision factor. Supervision is a process that encourage the organization members to contribute positively to achieve the organization goals. The benefits of supervision is to improve the effectiveness and efficiency of work. Performance will be good, if the supervision is good. Otherwise, if the supervision is bad, performance will be bad. This happens because the principle of supervision is to optimize work conditions that are conducive and comfortable to facilitate the implementation of tasks [13].

Present study results showed that there was no stastistical relationship between motivation factor and nurses' performance in preventing healthcare associated infections. This is supported by Suhendi (2010) who said that some motivations are not realized by the individual, and many individual behaviors are not recognized by himself, therefore some encouragement often appears due to dealing with unfavorable situations that are in the subconscious. Thus, a powerful inner drive to self often makes the individual become unable to understand his or her own motivation [14].

Similarly, there was no stastistical relationship between attitude factor and nurses' performance in preventing healthcare associated infections. Attitude is a readiness to act and not a certain motivation. Thus it can be said that attitude is not an activity, but is one predisposing factor of behavior. There are three components that must be owned to form attitudes such as beliefs, ideas and concepts of an object, and the tendency to act [12].

This study results showed that willingness to learn had a good level but not followed by good nurses' performance in preventing healthcare associated infections. According to reseacher, this can be caused by the existence of internal training course so that nurses only want to learn when the training session occur. The nurses' learning frequency decreased due to do a lot of routine tasks so the learning stimulus became less [15].

\section{CONCLUSION AND RECOMMENDATION}

Based on the findings of this study, it can be concluded that:

1. The majority of nurses' performance at Murni Teguh Memorial Hospital in 2017 have fair performance level $(64.3 \%)$ in preventing healthcare associated infections.

2. There is a relationship between education level, facilities and infrastructures factor, supervision factor and nurses' performance in preventing healthcare associated infections.

3. The supervision factor is the most dominant factor in relation to nurses' performance in preventing healthcare associated infections.

According to study findings, it is recommended that nurses' performance in preventing healthcare associated infections can be optimized by

1. Head of Nursing has to make head nurse effective on supervision to nurses in doing their jobs

2. General and Operational Director has to add facilities and infrastructure that are still not adequate

3. Personal general affair must have higher selection in education level of the new nurses

4. Education section conduct a good training internally and externally to the nurses in preventing infection.

\section{REFERENCES}

[1] L. F Yanti, Faktor-faktor yang memengaruhi perilaku perawat terhadap pencegahan infeksi nosokomial di ruang rawat inap kelas II dan III RSAU dr. Ernawan Antariksa tahun 2013, Jurnal Ilmiah Kesehatan, 6 (1); January 2014

[2] Darmadi, Infeksi Nosokomial Problematika dan Pengendaliannya. Jakarta: Salemba Medika, 2008

[3] World Health Organization (WHO), The Burden of HealthcareAssociated Infection Worldwide, 2010. Downloaded 20 February 2017. [Online]. Available: http://www.who.int.

[4] D. Jeyamohan, Angka Prevalensi Infeksi Nosokomial Pada Pasien Luka Operasi Pasca Bedah Di Bagian Bedah Di Rumah Sakit Umum Pusat Haji Adam Malik, Medan Dari Bulan April Sampai September 2010. Universitas Sumatera Utara. 2010, unpublished

[5] D. Pancaningrum, Faktor-Faktor Yang Memengaruhi Kinerja Perawat Pelaksana Di Ruang Rawat Inap Dalam Pencegahan Infeksi Nosokomial Di Rs Haji Jakarta Tahun 2011.Jakarta : Universitas Indonesia. 2011, unpublished

[6] P.S. Robbin and A.T Jugde, Perilaku organisasi. Edisi Bahasa Indonesia, edisi 12, PT.Salemba Empat, Jakarta, 2007

[7] Y.W. Herpan, Analisis Kinerja Perawat dalam Pengendalian Infeksi Nosokomial di RSU PKU Muhammadiyah Bantul Yogyakarta.KES MAS Vol. 6, No. 3, pp. 144-211, September 2012

[8] W. Setiyawati and Supratman, Faktor-faktor yang berhubungan dengan perilaku kepatuhan perawat dalam pencegahan infeksi luka operasi di ruang rawat inap RSUD dr. Moewardi Surakarta, Berita Ilmu Keperawatan ISSN 1979-2697, Vol . 1 No.2,pp. 87-92, Juny 2008

[9] K. Abdullah, A.I. Sidin, S.A. Pasinringi, Hubungan Pengetahuan, motivasi dan supervisi terhadap kinerja pencegahan infeksi nosokomial di RSUD Haji Makassar. Universitas Hasanuddin, 204, unpublished

[10] A.P. Mangkunegara, Manajemen sumber daya manusia. Cetakan kesembilan. Bandung : Remaja Rodakarya, 2008

[11] P.J. Simanjuntak, Manajemen dan evaluasi kinerja. Jakarta : Fakultas Ekonomi Universitas Indonesia, 2005 
[12] S. Notoatmodjo, Ilmu Perilaku Kesehatan. Jakarta : Penerbit Rineka Cipta, 2010

[13] S. Suarli, and Y. Bahtiar, Manajemen Keperawatan Dengan Pendekatan Praktis. Jakarta: Erlangga, 2010
[14] H. Suhendi, S. Anggara, Perilaku Organisasi, Bandung : C.V. Pustaka Setia, 2010

[15] S. Mahanani, Y.S. Dewi, W. Soerarti, Analisis Kinerja Perawat Pembimbing Klinik Dengan Pendekatan Teori Kinerja Dan Indikator Kompetensi. Jurnal Ners Vol. 9 No. 2, pp. 329-338, October 2014 